\title{
加工面アラサの解析（その 1)
}

—アラサ曲線の解析（第 5 報）

\author{
中村常 郎* \\ The Analysis of Roughness of Worked Surfaces (Part 1) \\ The Analysis of Surface Roughness Curves ( 5 th Report) - \\ Tsuneo NAKAMURA
}

In this report and next report, the surface roughness curves of practically worked surfaces are analysed by the methods described in the previous reports.

The surfaces of test piecces are worked by grinding, lapping and lathing, which are the most usual methods of machining. The surfaces worked by the first two are discussed in the present paper. The auto-correlation curves of the surface roughness are measured, and the periodicities of the worked surfaces are examined by an application of the accidental lines.

\section{5. 加工面アラサの解析 (その 1)}

\section{1 緒 言}

本報及び次報では 実際の加工面のアラサを既述の方法 で解析し，加工法とアラサの性質との関係をしらべる。 然し加工機構の検卻を目的としてはおらず，加工面の性 質が前述の考劣方でしらべうることを示すにすぎない。 加工法としては最も一般的な研削, ラッピング及び旋削 を考えてみる。

本報では前の 2 ついわる砥粒加工面を扱う。これは 多数の切れ及が同時に作用し，粗面を形成する物で自己 相関曲線より処理される。るたこのアラサ曲線に周期性 があるか否かを偶発直線によつて検討し，ほぼ自己相関 曲線に表われたと同程度の周期性を認めた。

\section{2 ラッピング面について}

自己相関曲線の測定法及び パワースペクトラムの計算 法は第 1，2報でのべたが，ここでは先づラッビング面 の3例について実際に自己相関曲線からパワースペクト ラムを近似計算しよう。

初めの試料怯鋼板 (記号 S) を60 及び500研磨砂 でラップした面々硝子板（記号 G）を500 研磨砂でラ ップした面の3種である。夫々のアラサ曲線を図 5-1 亿 示す。このアラサ曲線から第2 報でのべた光学的相関計 とより自己相関曲線を求め，この自己相関曲線 (の縦軸) を正規化せる物が図 5-2 の左側である。この図の右側は

* 北海道大学工学部 正会員

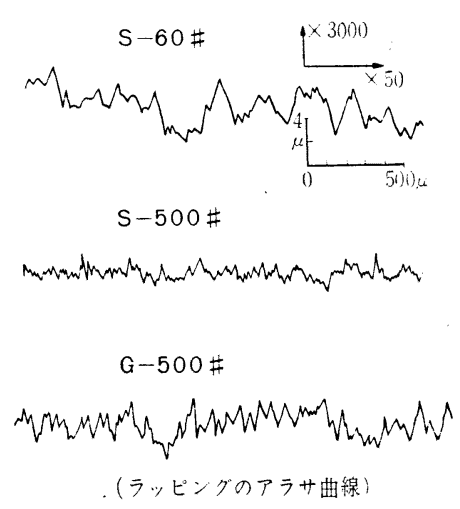

図 5-1

正規化自己相関曲線を目分量で周期分とランダム成分に 分離した物である。

この両成分は共に一次減衰と見なされ，第1報の式 (1-24) 前後でのべた如く周期成分 $\varphi_{P P}$, ランダム成分 $\varphi_{R R}$ は夫夕次式で表わされる。

$$
\begin{aligned}
& \left\{\begin{array}{l}
\varphi_{P P}(\tau)=\left|C_{P}\right|^{2} \cos w_{P} \tau \cdot e^{-a \tau} \\
\varphi_{R R}(\tau)=\mid C_{R}{ }^{2} e^{-\beta \tau}
\end{array}\right. \\
& \text { ここで } C_{P}{ }^{2} \text { は周期成分のパワー（アラサ振巾の } 2 \text { 乗 }
\end{aligned}
$$

比）の最大值であり， $\varphi_{{ }^{\prime}{ }^{p}}(0)$ の值でもある。 $C_{R}{ }^{2}$ はラ ンダム成分のパワーの最大值であり, $\varphi_{R R}(0)$ の值でも ある。 $\alpha$ 壮周期成分の空間周波数 $w_{P}$ からの抎がり（減 衰), $\beta$ はランダム成分の拚がりを表わす。

そこで四 5-2の右側で， $\tau=0$ の縦軸から夫々 $\left|C_{P}\right|^{2}$ 及 

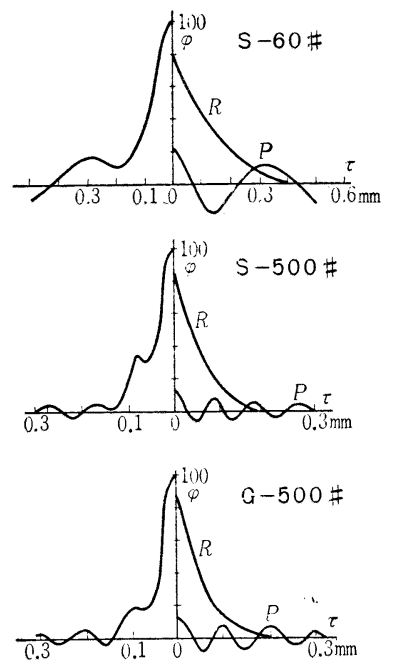

(自己相関曲線)

図 5-2

び $C_{R}{ }^{2}$ 兄求め, 椆期分のピッチから中心室閒周 波数 $w_{P}$ を求める。

また周期分の包絡線及びランダム分の曲線の減衰 $e^{-\alpha \tau}, e^{-\beta \tau}$ 加対数座標を用いて $\alpha, \beta$ は求まる。この 様沉して求めた值を表 5-1 の左5行以示す。

表 5-1

\begin{tabular}{c|c|cc|c|c||c|c}
\hline & $C_{P}{ }^{2}$ & $\alpha$ & $w_{P}\left(\frac{1}{m m}\right)$ & $C_{R^{2}}$ & $\beta$ & $\Phi_{P P}(0)$ & $\Phi_{R R}(0)$ \\
\hline $\mathrm{S} 60 \#$ & 22 & 3.8 & 19.4 & 78 & 8.7 & 58.0 & 90 \\
$\mathrm{~S} 500 \#$ & 14 & 8.0 & 72.2 & 86 & 20.0 & 17.5 & 43 \\
$\mathrm{G} 500 \#$ & 12 & 6.4 & 58.4 & 88 & 18.7 & 18.8 & 47 \\
\hline
\end{tabular}

また上式のフーリエ変換は式 (1-24)，（1-25）である が，こ礼总式 (5-3)，(5-4) とする。

$$
\begin{aligned}
& \Phi_{P^{\prime} l}(w)=\frac{\left.C_{P}\right|^{2} \alpha}{\alpha^{2}+\left(w_{P}-w\right)^{2}} \\
& \Phi_{R R}(w)=\mid \begin{array}{l}
C_{R_{1}^{2}}^{2} \beta \\
\beta^{2}+w^{2}
\end{array}
\end{aligned}
$$

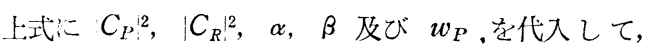
$w$ に対するパワースペクトラム $\Phi_{P P}(w), \Phi_{R R}(w)$ 曲 線在求める。乙机老図 5-3 江示す。

表5-1の右2 行は $w=0$ の各パワーの值を示す。

自己相関曲線の図 5-2 からもわかるが，パワースペク トルの図5-3 から周期成分は S 60 のラップ面が小さ いwでピークを持ちパワーは大きい。ランダム成分は 周期成分程の相晎がなく鋼板 500 の方がすそを引き， やや周波数領域の妄い即ち多数の細かい周期分をもつこ が無い。
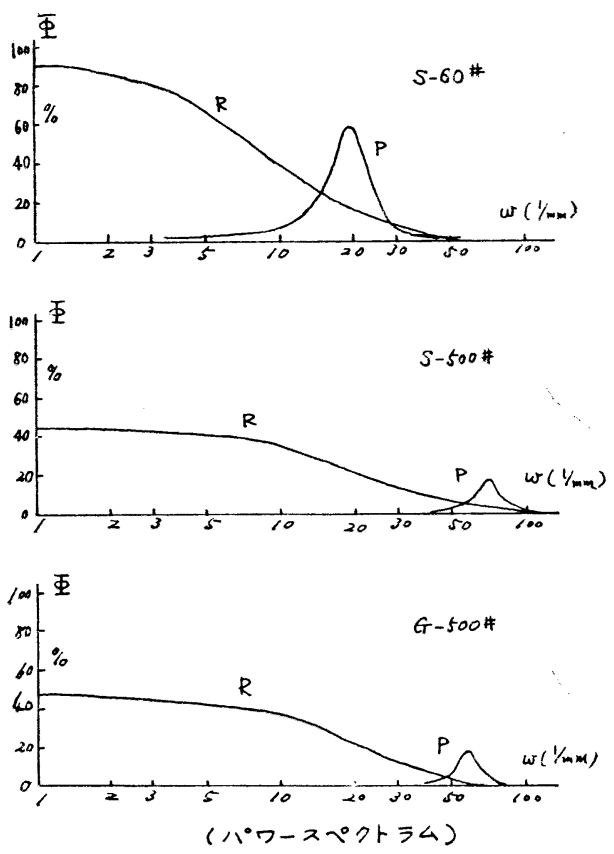

図 5-3

とを示している。500面について鋼と硝子では大きな差

次に硝子板を（記号 G）60\%，120\%，220 及び500 研磨砂であらした面について自 己相関曲線をとり，これについて検討して見 る。各試料面のアラサ曲線は図 5-4 に示す通 りで，その自己相関曲線を図 5-5に示す。縦 軸の絶対值を問題とせぬ（パワーをとらぬ） 為正規化せず，相関記録その物を示した。こ

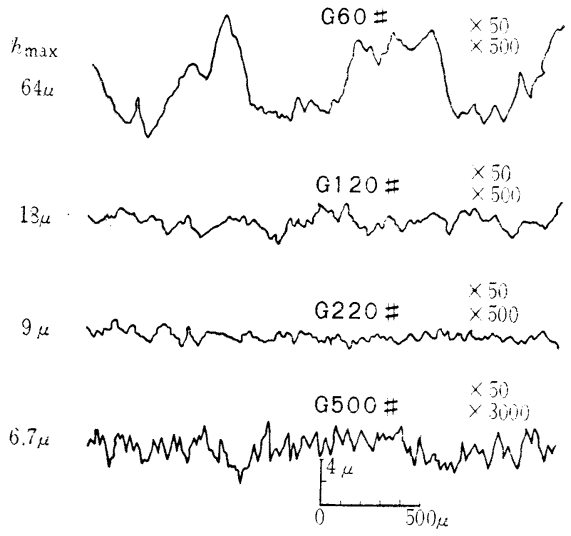

(ラッピングのアラサ曲線)

図 5-4 
れをランダムと周 期成分飞分解し, $\varphi\left(\tau_{0}\right)=0$ の相関 の巾 $\tau_{0}$ と周期 $T$ を測定し図の横に 示した。

次に各研磨砂の 粒径を規格表より 求めまたアラサ曲 線図 5-4 より最大 高さ $h_{\max }$ 求め る。

図 5-6 は横軸に 各粒径をとり, 縌 軸に $\tau_{0}, T$ 及び $h_{\text {max }}$ をとつた物 である。これから $h_{\max }$ は活济粒径 の $1 / 3$, ピッチ $T$
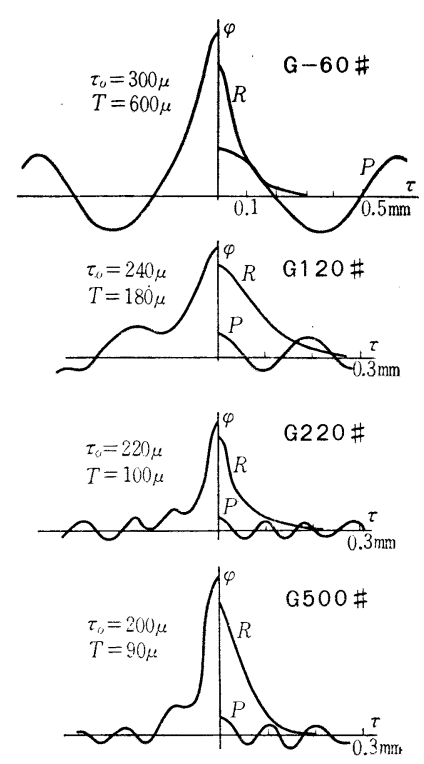

(自己相関曲線)

図 5-5

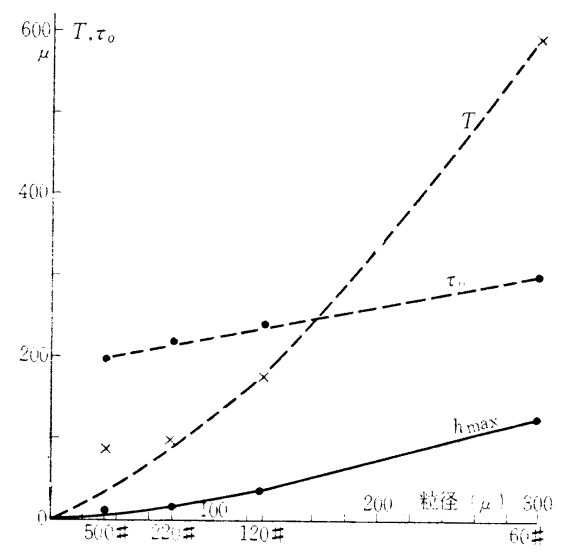

図 5-6

は粒径の 2 倍程度, 相関の幅 $\tau_{0}$ は大きくは变化しない が粒径と共に減少している。

以上ラップ加工面について光学的にアラサの自己相関 曲線を求め，それからパワースペクトラムを計算した訳 であるが，相関曲線から周期分とランダム成分を分離与 る際の精度は低いので，周期成分の周期，振幅などの数 值は誤差が大きいと考えざるを得ない。

\section{3 研削加工面について}

研削加工面々ついて, 䃌石のドレシング, 粒度, 結合 度更に送り等の変化が相関曲線にどの様に 表われるかを しらベて見る。
加工機注精密油圧式平面研削盤 (岡本製), 估石の大き さは 8 " $\times 3 / 4 " \times 2 "$, 研石は WA 24 J, WA 46 H 及心゙ WA 80 K の 3 種で, 試料は鋼材である。

先づドレシングの影響を見る為に 46 研石を，故意 に粗く約 $270 \mu$ の送りでドレスしたものとやや粗く $100 \mu$ の送りでドレスしたものを用い，この2種について研削 盤の送りを約 $1 ， 0.5$ 及び $0.1 \mathrm{~mm}$ の種で加工した。 この加工面のアラサ曲線を図 5-7 に相関曲線を図 5-8 に

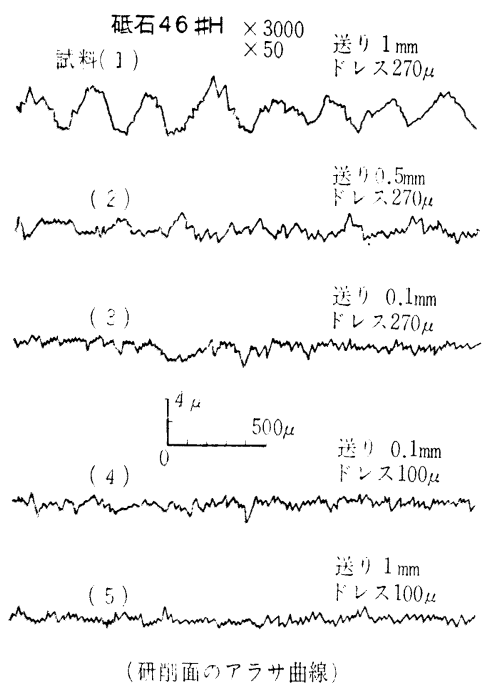

図 5-7
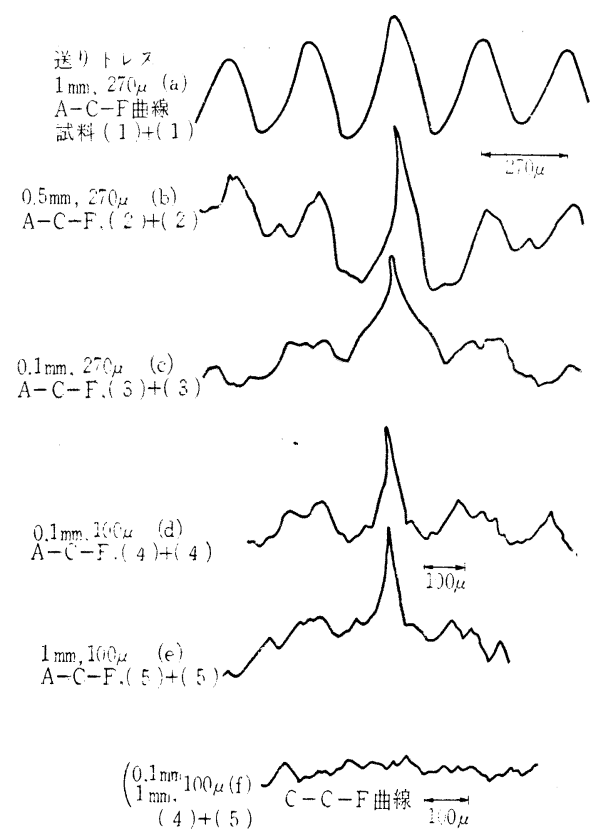

図 5-8 
示す。

アラサ曲線の測定倍率は繸 $\times 3000$, 横 $\times 50$ で, 碰石の ドレシングと研削送りの概略值は図仁示してある。図 5-8

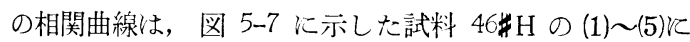
ついてそれ自身の自己相関が (a) 〜 (e), 試料(4)と(5)の相 互相関が (f) であり，いら゙れも記録曲線そのま李を示し ている。

図 5-8 の自己相関曲線 $(\mathbf{a})$ ，(b) 及び (c) からは粗い

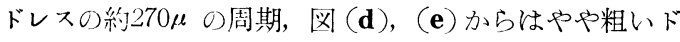

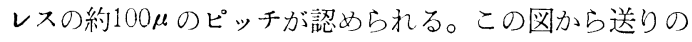
差は認嫫難い。また図（f）はドレス $100 \mu$ の送り $1 \mathrm{~mm}$

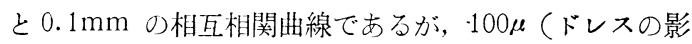
響) とその $1 / 3$ 程度の周期が認められる。

次比 24J研石の研削加工面で送りの影響を考克て見 る。図 5-9 はこの加工面をダイヤモンド触針（触針半径 約5 $\mu$ )で走查した粗さ曲線で, 図 5-10はこのアラサ曲

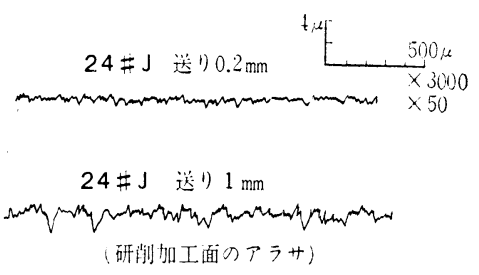

园 5-9

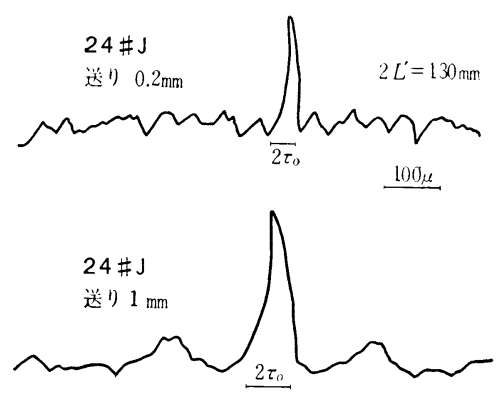

(自己相関曲線)

図 5-10

線の自己相関曲線である。送り $0.2 \mathrm{~mm}$ と $1 \mathrm{~mm}$ の差は 認められる。然し周期の大きさは送りの約 $1 /{ }_{5} \sim 1 / 6$ ( $\mathrm{T}=$

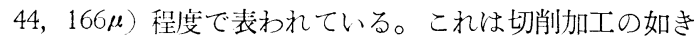
送りマークが単純猿わ机ないで，ドレシングと送りの 影響が重なり合つて表われたと考兄られる。

送りを無理に大きく（例自ば $1 \mathrm{~mm}$ 等）した場合，測 定距離を充分上ればこの送りの影響も認められる。

普通の範囲内での研削条件の差（前記研削盤を使用し て）以相関曲線炕大きは表われず，また粒度差，結合
度差の影響も WA 80 K 砥石の結果を含めてもここで は認められなかつた。

\section{4 砥粒加工面の周期性}

単一风先による加工例えげ切削加工ではアラサ曲線に 周期性があるのは当然であるが，砥粒加工特にラッピン グ加工ではアラサ曲線に周期性があるか否か明かでな い。筆者の扱つた䃨粒加工では研削, アブレシブペルト のみならずラッピング加工にもアラサの自己相関曲線の 中に周期性が認められる。

この自己相関曲線滆期性があれげ，元のアラサ曲線 飞周期性があることは予想されるが，疑似周期のまじる 心配もある。第 2 報にのべた様に光学的相関計は理論的 とは無限大なる可き試料長 2 L が必ずしも大きくない。 試料長が短い場合外部から周期が混入する憂があるが, この点は ミ2-1 (c) で検討した結果試料長は充分である う。然しここでは別な方面からこの周期性の有無を検討 して見る。

\section{(a) 偶発性淔線}

地震の生起等が偶発か周期性を持つかについては古く から研究されている。これらの数学的取扱( ${ }^{23224)}$ の偶発 函数 $u(x)$ によつてアラサ曲線洞期性があるか否かを 検討して見る。

アラサ曲線の一つの凹凸の山注目し，その(最後の) 山 (頂) から $x$ 離れた $d x$ 間炏次の山 (頂) が表われ る確深を $u(x) d x$ と打く。

考光る範囲の山凸の山と山との間隔つ総数を $N$ とす る。山の間隔が $x$ から $x+d x$ までの数を $N q(x) d x$ と打く。山の間隔が $x$ 以上の数を $N p(x)$ と沶く。

然るとき

$$
p(x)=\int_{x}^{\infty} q(x) d x
$$

$x$ 迄山が表われぬ状体が続いている $N p$ の中, $N q d x=$ $-N d p$ だけは $d x$ 間汕山が表わ机る。従つて $x$ 迄山が 表われずと続いたことが解つている時，その後の $d x$ 飞 山が表われる為の確率 $u d x$ は次の如く招きうる。

$$
u(x) d x=-\frac{d p}{p}=-d \log p
$$

また間隔の平均長さを $T_{m}$ とすると，

$$
T_{m}=\int_{0}^{\infty} x q(x) d x
$$

さて山の表われ方が周期性でなく偶発性である場合には $u$ は $x$ 飞無関係である。

23) 福島浩：岩波科学文献抄, 15 (昭12)

24）渡辺慧：理研菓報, 15 (1936) 1083. 
即ち偶発の場合注は次の如く䊉くこともできる。

$$
u(x)=m \text { (常数) }
$$

式 (5-5) より

$$
-d \log p=m d x
$$$$
\therefore p=e^{-m x}
$$

従つて $q=m e^{-m x}$

$$
\text { また } T_{m}=\frac{1}{m}
$$

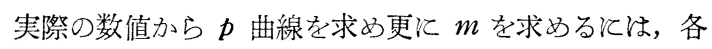
間隔に対応寸る山の数 $N q d x$ 及び $N$ を数元これから $q$ 更汇 $p$ を求める。

$q(x)$ 曲線から $m$ を求め, また $u(x)$ の確摔函数を兄 がき周期性の検討を行うことができる。

\section{(b) 礔粒加工面の周期性の検討}

ここでは実例として軟鋼 Sを60 及び500些粒でま た硝子Gを120末 及ご500\#砥粒でラッピングした面と， 黄銅を 100 研粒, 軟鋼を 120 と 220 研粒のアブレシ ブバルトで加工した面とをしらべて見る。

$p(x)$ 曲線, 確率曲線 $u(x)$ を求めるに忙, 周波数 (周 期) の範囲と各周期の個数が相当必要である。それはア ラサの山のピッチが大きい物や小さい物饬寄つては困 るし, 測定間隔 $d x$ も記録曲線上 $1 \sim 2 m m$ が最小であ りアラサ記録曲線の縦横倍率をその目的汇合う様撰ば放 ばならない。これは必ずしも他の目的と合致しないで， 図5-9 亿示した研削加工面（細かすぎ）図 5-4 亿示した 硝子 60 ラッピング面（あらすぎ）のアラサ曲線等は上 の梯な計算汇不適当である。

(i) 軟鋼ラッピング面 (60) 500 玨粒)

両者のアラサ記録曲線及びこれを2段階汇巨視的飞見
たアラサ曲線の一部を図 5-11 に示うっ。縦横つ偉率はメ

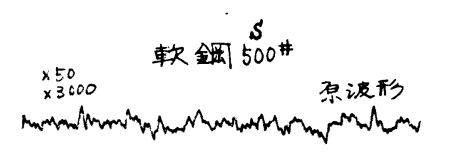

50, ×3000 であ る。网加解る様 こアラサ記録曲線 から克明に細かい ピッチを数えた丈

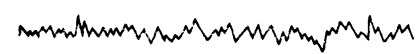

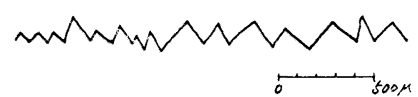

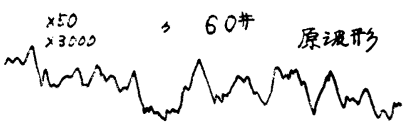

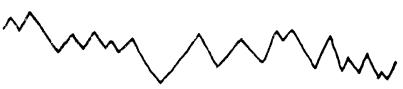

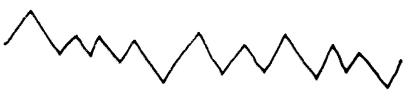

ラツピング゚アラサ曲潒

図 $5-11$

ではあらいビッチ 㳉表わ杞ない。そ こで $\mathrm{S} 500$ 沉つ いて云况ば，大略 先づ高さ $1 \mathrm{~mm}$ 以 下次淿 $3 \mathrm{~mm}$ 以下 小山を無視した 2 種のアラサ曲線を 新た作る。了種 のアラ少曲線汇つ いて $2 \mathrm{~mm}$ 閒隔 $(=d x)$ 每のピッ 于飞対灾与る簓数 をとり,箘数と $d x$

の曲線をえがきその包絡線から $N q d x$ が定京る。奏際 に注手数を省いて各間隔の最大箇数を $N q d x$ とする。

なおアラサ曲線を巨視的衹る場合 無視する細かい山 の数值，閏潭を見当で撰んだのであるが包絡線から $N q$ $d x$ をチェックしたので閒違は少ない上考光る。

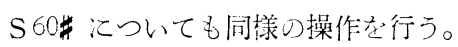

図 5-11 から各間隔（アラサ曲線上 $d x=2 \mathrm{~mm}$ ) 法対す る $N q d x, \sum N q d x$ を求奶, こ机より $q, p, \log p$ 等

\begin{tabular}{|c|c|c|c|c|c|c|c|c|c|c|c|c|}
\hline \multirow{2}{*}{$\begin{array}{c}d x \\
\mathrm{~mm}\end{array}$} & \multicolumn{4}{|c|}{ S 60} & & & \multicolumn{6}{|c|}{ S 500\# } \\
\hline & $N q d x$ & $q$ & $p$ & $\log _{e} p$ & $d \log p$ & $\frac{d \log p}{d x}$ & $N q d \boldsymbol{x}$ & $q$ & $p$ & $\log _{e} p$ & $d \log p$ & $\frac{d \log p}{d x}$ \\
\hline $0 \sim 2$ & 36 & 0.327 & 1.000 & 0 & 0.38 & 0.19 & 191 & 0.702 & 1.000 & 0 & 1.21 & 0.51 \\
\hline $2 \sim 4$ & 35 & .318 & 0.671 & -0.38 & .66 & 0.33 & 55 & .202 & 0.298 & -1.21 & 1.13 & 0.57 \\
\hline $4 \sim 6$ & 20 & .182 & .353 & -1.04 & .72 & .36 & 9 & .033 & .096 & -2.34 & 0.43 & 0.22 \\
\hline $5 \sim 8$ & 4 & .036 & .171 & -1.76 & .10 & .05 & 4 & .015 & .063 & -2.77 & 0.27 & 0.14 \\
\hline $8 \sim 10$ & 3 & .027 & .135 & -1.86 & .36 & .18 & 6 & .022 & .048 & -3.04 & 0.61 & 0.31 \\
\hline $10 \sim 12$ & 3 & $\|$ & .108 & -2.22 & .29 & .15 & 4 & .015 & .026 & -3.65 & 0.85 & 0.43 \\
\hline $12 \sim 14$ & 3 & $\mu$ & .081 & -2.51 & .41 & .21 & 2 & .007 & .011 & -4.50 & 1.02 & 0.51 \\
\hline $14 \sim 16$ & 1 & .009 & .054 & -2.92 & .18 & .09 & 1 & .004 & $.00 \%$ & -5.52 & & \\
\hline $16 \sim 18$ & 3 & .027 & .045 & -3.10 & .91 & .46 & & & & & & \\
\hline $18 \sim 20$ & 1 & .009 & .018 & -4.01 & .69 & .35 & & & & & & \\
\hline $20 \sim 22$ & 1 & .009 & .009 & -4.70 & & & & & & & & \\
\hline$\sum N q d x$ & 110 & & & & & & 272 & & & & & \\
\hline
\end{tabular}
を計算した物を表 5-2 に示子。

表 5-2 

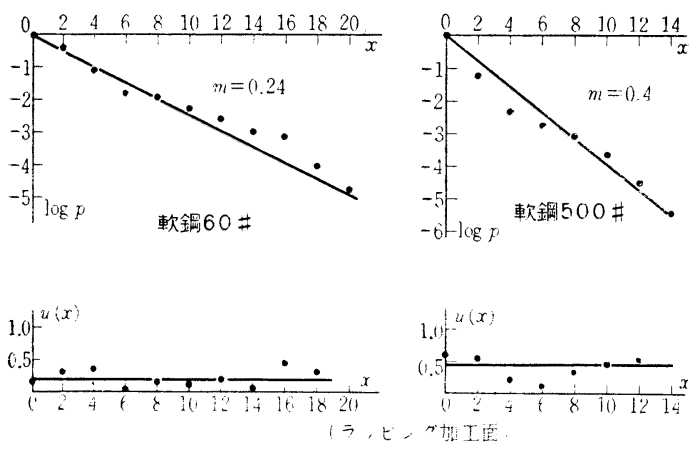

図 5-12

表 5-2 0 $\log _{e} p$ 及ご $u(x)=-d \log p / d x$ を図 5-12 亿示与。式 (5-7) より $\log _{e} p=-m x$

従つて $\log _{e} p(x)$ 曲線より $\mathrm{m}$ が定まる。また $\boldsymbol{u}(x)$ 曲線儿式 (5-6) の $u(x)=m$ なる偶発直線を 示すが，この直線よりはずれた位置 $(x)$ が周期性 を示すととになる。な扮アラサ曲線の横倍率は $\times 50$ であるから。 $x m / 50$ が試料上の長さとなる。

図5-12の S60 S S007面の $u(x)$ 曲線浪偶発 性を示すと考えるより，夫々 $300 \mu, 100 \mu$ の附近に 周期性があると考えた方が妥当であるう。

また $\mathrm{m}$ は夫々 $0.24 ， 0.4 て ゙ あ り ，$ 従つて間隔の平

均長さ $T_{m}$ は $84 \mu, 50 \mu$ となる。

(ii) 硝子ラッピング面 (120 500 砥粒)

これらのアラサ曲線は既に図5-4に示したがその $\log _{e}$ $p(x), u(x)$ 曲線を図 5-13 亿示す。
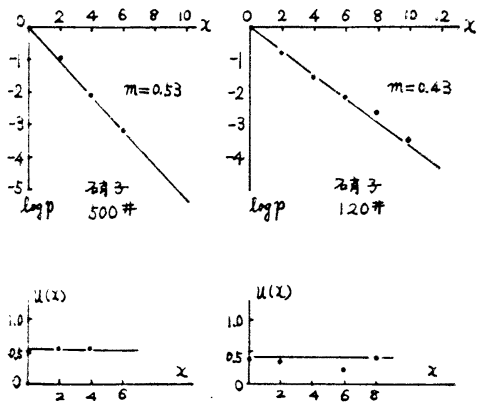

(ラッピング加エ而)

図 5-13

$\log p(x)$ 曲線から 120 , 500 面が夫々 $m$ は 0.43, 0.53 従つて夫々 $T_{m}$ 注 $46 \mu, 38 \mu$ となる。

$u(x)$ 曲線から 120 面は $120 \mu$ 辺に周期が見られるが 500 面怯周波数範囲が少く資料不足でなんとも云えな w。 (iii) アブレシブベルト加工面

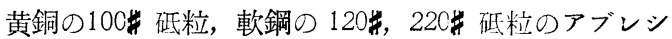
ブベルト加工面のアラサ曲線及び自己相関曲線は既に 図 2-3 亿示したがその $\log p(x), u(x)$ 曲線を図 5-14 亿 示す。

$\log p(x)$ 曲線より夫々の $m$ は $0.39,0.42$ 及び0.47 と 求められ, 従つて $T_{m}$ は夫々 50,48 及び $43 \mu$ となる。

$u(x)$ 曲線からはいづれも偶発性のみとも見られるが 特に 120 面に周期性が認められず，100れ，220 面には 夫々 $120 \mu, 80 \mu$ 辺汇周期がやや認められる。

以上の結果と前述の自己相関曲線より 求めた周期成分 との関係を総括的に考えて見よう。
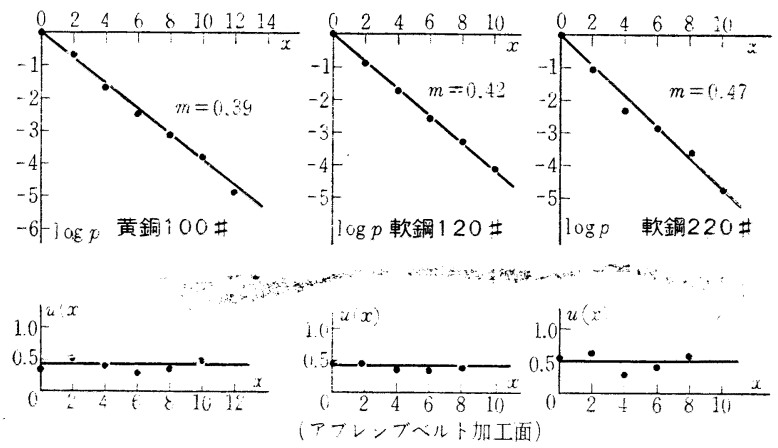

図 5-14

軟鋼 120 アブレシブベルト加工面以外（500\# Gを除 き）恃体偶発直線よりの偏倚から周期成分のあること が認められる。

図 5-15 横軸に自己相関曲線よりの周期 $(T)$ を，縦 軸に $u(x)$ より求めた周期 $\left(T^{\prime \prime}\right)$ と平均閒隔 $\left(T_{n}\right)$ を 示す。

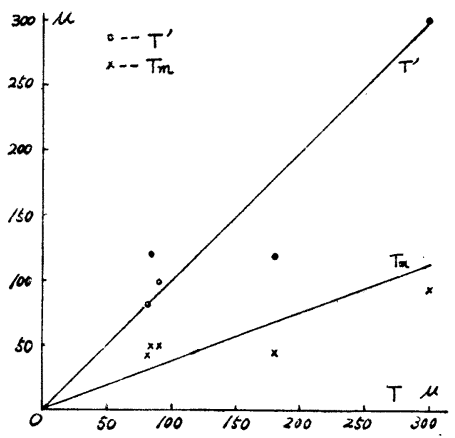

図 5-15

両者の周期成分の周期はほぼ近い值をとり，これらの アラサには周期性があると考えるのが至当であるう。

平均間隔 $T m$ は図から大体周期の $1 / 3$ 程度の值を示 
しているc

\section{結 論}

本報では加工面のアラサ曲線の相関曲線とよる解析結 果を考察した。加工法としてラッピング，研削を主なる 対称とした。ラッピング加工面から周期成分が認められ
その周期は他の測定值と妥当な関倸にあり，また研削加 工面飞も周期性が認められるが普通の範囲の加工条件で は自己相関曲線との関連が認められなかつた。また偶発 直線により砥粒加工面を検討したが，ほぼ自己相関曲線 より得たと同様な周期分を認めた。

(1959，8月26日受付)

\section{一表紙写真説明—}

\section{真空焼結 炉}

本機は高真空焼結用に設計した装置で最高 $2,200^{\circ} \mathrm{C}$ の 高温が得られる。

用途は Ta.コンデンサー用シンターボディの焼結酸化 ウランの水素雾囲気中に於敌る焼結, その他サーメット, Ta. Mo. Nb 等レアーメタル焼結用として使用される。 仕様

排気系 4 时油拡散ポンプ 2 台
$500 \mathrm{l} / \mathrm{min}$ 油廻転ポンプ 1 台

真 空 度 容積, 时 $1 \times 10^{-5} \mathrm{mmHg}$

炉内積 $60 \phi \times 180 \mathrm{H}$

$$
\begin{array}{lll}
\text { 反 射 板 } & \text { 数層 } \\
\text { 炉内温 度 } & 2000^{\circ} \mathrm{C} \sim 2200^{\circ} \mathrm{C} \\
\text { 炉内雾囲気 } & \text { 調節可能 } \\
\text { 電 } & \text { 源 } & \mathrm{P} 200 \mathrm{~V} \quad 12 \mathrm{KVA}
\end{array}
$$

特長

炉内に耐火物を全然用いないので非常に真空度が良く 又熱容量が少ないので昇温時閒が短く，炉内熱分布が非 常に均一である。

又温度調節が行い易い。

\section{営業品目}

回転型真空ポンプ 油拡散ポンプ

真空乾燥装置各種真空装置真架洷

\section{TSK 東京真 空機械株 式会 社} 本 社 東京都大田区矢口町 819 電 (738) 1156 8 大阪出張所大阪市西区立売堀南通5 (泰平産業K K内) 名古屋代理店 名古屋市中区東袋町 202 (株) 小沢製作所 九州代理店福岡市万行寺前町38 東洋归紙福岡出張所 